\title{
Geçmişten Günümüze Türk Romanında Kıskançlığın Etkileri ve İzleri
}

\section{Impacts and Traces of Jealousy in Turkish Novel from Past the Present}

Uygur Gürbüz, Selda (2021). Türk Romanından Örneklerle Edebiyat ve Kıskançlık, İstanbul: Çizgi Kitabevi, 248 s., ISBN: 978-605-196-657-1.

\section{Burçin Ün ${ }^{1}$ (D)}

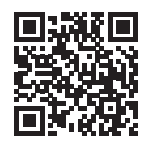

${ }^{1}$ Yüksek Lisans Öğrencisi, Trakya Üniversitesi (Namık Kemal Üniversitesi Ortak Program), Sosyal Bilimler Enstitüsü, Türk Dili ve Edebiyatı Anabilim Dalı, Edirne, Türkiye

ORCID: B.Ü. 0000-0002-6719-7990

Sorumlu yazar/Corresponding author: Burçin Ün,

Trakya Üniversitesi (Namık Kemal Üniversitesi Ortak Program), Sosyal Bilimler Enstitüsü, Türk Dili ve Edebiyatı Anabilim Dalı, Edirne, Türkiye E-mail: burcinunn@gmail.com

Başvuru/Submitted: 19.10.2021

Kabul/Accepted: 02.12.2021

\section{Atuf/Citation:}

Un, B. (2021). Geçmișten günümüze Türk romanında kıskançlığın etkileri ve izleri [Selda Uygur Gürbüz'ün “Türk Romanından Örneklerle Edebiyat ve Kıskançlık" adlı eserinin değerlendirmesi]. TUDED, 61(2), 793-797. https://doi.org/10.26650/TUDED2021-1012170

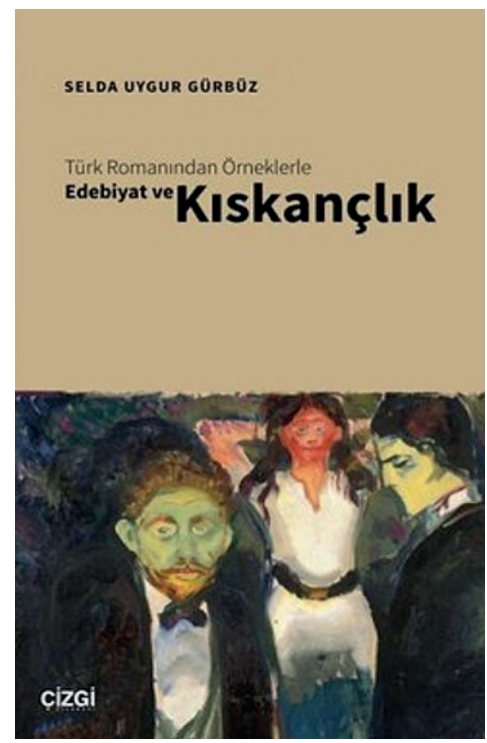

Anahtar Kelimeler: Modern Türk Edebiyat1, Selda Uygur Gürbüz, edebiyat ve psikoloji, kıskançlık, roman

Keywords: Contemporary Turkish Literature, Selda Uygur Gürbüz, literature and psychology, jealousy, novel 
Dr. Öğr. Üyesi Selda Uygur Gürbüz’ün Eylül 2021 tarihinde Çizgi Kitabevi tarafindan yayımlanan çalışması Türk Romanından Örneklerle Edebiyat ve Kıskançlık adını taşımaktadır. Eser, Kaynakça bölümü de dahil olmak üzere toplam iki yüz kırk sekiz sayfadan oluşur. Giriş bölümünde çalışmanın ana konusunu teşkil eden kıskançlığın muhtelif tanımlamaları verilirken aynı zamanda diğer disiplinler ile ilişkisi de irdelenir. Bu bölümün haricinde çalışmanın dört başlıktan oluştuğu gözlemlenir. Bu başlıklar; "Mitoloji, Felsefe ve Psikolojide Klskançlık", "Oidipus Kompleksi ve Baba-Oğul İlişkileri Bağlamında Kıskançlık, "Aşk, Cinsellik ve Kiskançlık”, "Narsisizm ve Kötücüllük Bağlamında Klskançlık” adlarını taşır.

Gürbüz, ele alınan bu çalışmasında insanın var olduğu ve diğer bireyler ile ilişki kurmaya başladığı andan itibaren geliştirdiği bir duygu durumu olan kıskançlığı merkeze alır; kıskançlığın edebî metinlerdeki karakterler üzerinde süregelen yansımalarının izini sürmeyi amaç edinir.

Giriş bölümü kıskançlık kelimesinin sözcük etimolojisi de dahil olmak üzere tarihsel kökenine değin kapsamlı bir araştırma içerir. Kıskançlığın eski ve çağdaş Türkçe sözlüklerdeki manasının ortaya konulmaya çalışıldığı bu kısımda Batılı kaynaklardan alınan tanımlamalar da önemli yer tutar. Özellikle kıskançlık ile çok sık karıştırılan "haset”, “gıpta”, “imrenme ” gibi duygu durumlarının kıskançlıktan farkını ortaya koyan Gürbüz, -ele alınacak edebî metinlerde de görüleceği üzere- kıskançlığın oluşabilmesi için üç farklı bireyin içinde bulunması gereken bir durumun olması gerektiğini izah eder.

Kitabın Mitoloji, Felsefe ve Psikolojide Klskançlık adını taşıyan birinci bölümü çeşitli alt başlıklara ayrılır. Bu bölümde üzerinde durulan en önemli mesele kıskançlığın diğer disiplinlerin araştırma alanında ne şekilde ortaya çıktığg 1 ve gözlemlendiği meselesidir. Mitolojide Klskançlık alt başlığında arkaik dönemin en önemli metinleri sayılan mitlerdeki kıskançlık temasının belirgin bir şekilde gözlemlendiği dikkat çeker. Gürbüz, modern dönemde üretilen ve kıskançlık teması etrafında şekillenen pek çok metnin kaynağını teşkil eden Sofokles'in Oidipus anlatısı üzerinde durur. Yalnızca Oidipus değil daha pek çok mit gerek iktidar kavgasından gerek femme fatale tiplemesinden gerekse aşk hissinden meydana çıkan kıskançlık temini sıklıkla konu edinir. Felsefede Klskançlık alt başlığında felsefenin rasyonalist düşün adamlarından Spinoza'nın kıskançlığa dair görüşlerine yer verilir. İnsanın kıskançlık duygusunu yorumlamak adına en iyi yol gösterici olan, bireyin ruh ve davranışını incelemeyi esas edinen bilim elbette ki psikolojidir. Bu bağlamda Gürbüz, Psikolojide Kıskançlık alt başlığı altında kıskançlığı 19. ve 20. yüzyılın önemli psikanalistlerinin -Freud, C. Gustav Jung, Adler, Lacan, M. Klein, K. Horney, H. Kohut, Otto F. Kernberg- görüşleri ışığında aydınlatmaya gayret eder. İleriki bölümde ele alınacak edebiyat metinleri de adı geçen psikanalistlerin görüşleri ışı̆̆ında ele alınacaktır.

Gürbüz, kitabın Oidipus ve Baba-Oğul İlişkileri Băglamında Kıskançlık isimli ikinci bölümünde çalışmasının asıl amacı olan kıskançlığın edebiyat metinlerindeki izlerini sürmeye başlar. Önceki bölümlerde verilen teorik bilgilerin uygulama safhasına geçildiği bu bölümde Oidipus Kompleksi temel alınarak Yaşar Kemal'in Yağmurcuk Kuşu ve Orhan Pamuk'un Kırmızı Saçlı Kadın romanlarındaki başkarakterler, Freud'un Oidipus anlatısındaki çatışmadan yola çıkarak meydana getirdiği teori bağlamında detaylıca incelenir. 
Gürbüz, Oidipus Komleksi’nin baba ile oğul arasındaki çatışmadan kaynaklı oğulun babaya karşı beslediği kıskançlıktan ortaya çıktığını ifade ederken yapmış olduğu tanımlama bu bölümde ele alınan iki romanın ana karakterlerinin iç dünyasını psikanalitik açıdan incelemeye olanak tanır:

Asıl kıskançlığın sebebi babaya duyulan sevgi değil, annenin babaya ve penise sahip olmasıdır. (...) Erkeklerde anne göğsüne duyulan haset çok önemli bir etkendir. Eğer güçlüyse ve bu yüzden oral doyum zayıflamışsa, nefret ve kaygılar vajinaya aktarılır. Cinsel ilişki düşkünlüğü ve eşcinselliğin sebepleri arasında bu aktarım da vardır. Anneden yüz çevirmek, baba ve penisiyle bir olduğunu düşünmek sevilen kadına ihanet etme düşüncesini de doğurur (s. 60).

Yaşar Kemal'in Yağmurcuk Kuşu romanı otobiyografik özellikler taşıyan bir metindir. Kemal'in aile yaşamı ile de benzerlikler arz eden romandaki ana karakterler Mustafa ve Salman isimli iki kardeştir. Ancak Salman'ın aileye sonradan katılışı, öz oğulun Mustafa oluşu ve baba İsmail Ağa'nın Mustafa'ya olan temayülü Salman'daki baba sevgisini kıskançlığa dönüştürür. Oidipus anlatısında görüldüğü üzere babası Laios'u öldürüp annesi Iakoste ile evlenen Kral Oidipus gibi Salman da baba-oğul kıskançlığının bedelini İsmail Ağa’ya ödetir.

Kırmızı Saçlı Kadın, ana karakter Cem'in babasıyla kuramadığı yakınlığı çırağı olduğu Mahmut Usta'da arayışının ve onunla kurmaya çabaladığı baba-oğul ilişkisinin çevresinde gelişim gösteren bir romandır. Her iki erkek için de büyük önem taşıyan kırmızı saçlı kadın, Cem'in ve Mahmut Usta'nın aralarında oluşacak gizli kıskançlığın en önemli unsurudur. Bu nedenle Oidipus Kompleksi'nin en belirgin örneğini oluşturan Pamuk'un bu anlatısı, "her erkeğin içinde taşıdı̆̆ babayı öldürme isteği üzerinedir” (s. 87).

Kıskançlığın pek çok nedeninin olduğu; bireyi kuşatan ve çoğu zaman hayatını çekilmez kılan zorluklara sebebiyet verdiği bilinen bir gerçektir. Çalışmanın üçüncü başlığı olan $A s ̧ k$, Cinsellik ve Kıskançlık adlı bölüm, kıskançlığın başka bir boyutu olan duygusal ve cinsel manada hissedilen kıskançlığı konu edinir. Bu bölümde toplam üç roman incelemeye tabi tutulmuştur. Bunlar; Nabizâde Nâzım'ın Zehra'sı, Mehmet Rauf'un Kâbus 'u ve Orhan Pamuk'un Masumiyet Müzesi adlı romanıdır. Eserlerin incelemesinde aşk kıskançlığı üzerine geniş çaplı incelemeler yapan psikanalist Daniel Lagache'ın görüşleri önemli bir yer tutar; ardından Freud, Lacan, Klein ve Kernberg'in teorileri bağlamında başkarakterler çözümlenmeye çalışılır. Aşk vasıtasıyla hissedilen kıskançlığın pek çok nedeni bulunur. Sevilen kişinin aşkına rakip olabileceği düşüncesiyle bir başkasına kıskançlık duyulabilirken aynı zamanda "cinsel kıskançlık" adı verilen ötekinin bir arzu nesnesi olduğu ve ona sahip olma isteği ile dolu olunduğu anlarda da kıskançlık hissedilebilmektedir.

Bu bölümde ele alınan üç romanın karakteri de son derece kıskanç, sevdikleri insanlara ve kendilerine dünyayı çekilmez kılan şahıslardır. Zehra'da başkarakter Zehra'nın çocukluğuna inilerek kıskançlığının nedenleri ortaya konmaya çalışılır. Kâbus 'un Aziz Nihat'1 ise kıskançlığının meydana getirdiği bir sinir buhranı içinde karısını öldürüp öldürmediğinin 
sorgulamaları içerisindedir. Masumiyet Müzesi'nin tatminsiz Kemal'i bir arzu nesnesi olarak Füsun'u çevresindeki herkesten kıskanmakta, onu elde edebilmenin yollarını aramaktadır. Ancak Gürbüz, Kemal'in Füsun'a karşı duyumsadığı kıskançlığg René Girard'ın sınıflamaları ölçüsünde değerlendirirken şu açıklamada bulunmayı ihmal etmez: "Iç̧sel dolayıma göre Kemal’in kıskançlı̆̆ı klasik kıskançlık tanımlarından farklı olarak başkalarının arzuladığını arzulamaya yönelik bir dürtü, yani taklit arzudur” (s. 157).

Kahramanların davranışlarının asıl nedenini psikanalistlerin görüşleri 1şığında aydınlatmaya gayret eden Gürbüz, “öteki”, “arzu nesnesi”, “jouissance” vb. pek çok kavramın nezdinde kahramanların davranışlarının altında yatan psikolojik nedenleri irdelemeye çalışır; Freud'un ve Otto Kernberg'in görüşleri nezdinde fahişeye duyulan aşk bağlamında da karakterleri ele alır.

Çalışmanın dördüncü başlığı ise Narsisizm ve Kötücüllük Bağlamında Kıskançlık adını taşımaktadır. Bu bölümde ele alınan eserler ise; Nahid Sırrı Örik'in Kıskanmak, Nihal Yeğinobalı'nın Mazi Kalbimde Bir Yaradır, Reşat Nuri Güntekin'in Bir Kadın Düşmanı ve Ahmet Hamdi Tanpınar'ın Huzur isimli romanlarıdır. Gürbüz, hissettiği kıskançlığın haset ile benzer özellikler taşıdığı karakterlerin yanı sıra narsistik özellikleri nedeniyle yaşadıkları davranış bozukluğu bağlamında roman kahramanlarını detaylı bir incelemeye tabi tutar. Karakterler, çeşitli psikanalistlerin görüşleri ışığında aydınlatılmaya çalışılır. Kimi psikanalist bu kötücül hissiyatın bebeklik döneminde anne ile kurulan ilişkiden kaynaklı olduğunu ileri sürer; kimi ise kökeni Yunan mitolojisinden gelen narsisizm (özseverlik) sebebiyle ortaya çıktığı görüşündedir.

Kıskanmak romanının kıskanç başkarakteri Seniha, ağabeyi Halit'e büyük bir kıskançlık besler. Gürbüz, Seniha'nın bu duygu durumunu pek çok psikanalistin görüşü 1şığında aydınlatmaya çalışır. Seniha'nın kıskançlığının Freud'un kız çocuklarında gözlemlenen “penis kıskançlığı” kavramı ile açıklamasının yanı sıra Klein'in “iyi meme kötü meme” ve Kernberg'in "narsisist kişilik yapılanması" bağlamında incelediği görülür. Aynı kategoride incelemeye tabi tutulan Mazi Kalbimde Bir Yaradır ve Bir Kadın Düşmanı kuzene karş1 duyumsanan kıskançlığı konu edinir. Bir Kadın Düşmanı'nın Sara'sı ve Mazi Kalbimde Bir Yaradır'ın Süsi'si Simone de Beauvoir'ın kadın güzelliğine dayalı psikanalitik incelemesi bağlamında ele alınır. Dördüncü bölümün son romanı Huzur 'dur. Gürbüz, Suat'ın ve Suat ile kıskançlık yönünden özdeş sayılabilecek Mümtaz'ın kötücül yanını özellikle Horney'in nevrotik kişiye dair teorileri bağlamında titiz bir şekilde inceleyerek elde ettiği verileri ortaya koyar.

Gürbüz, eserinin sonuç kısmında çalışma boyunca incelemeye olanak tanıyan kıskançlığın ortaya çıkışını ve romanlarda gözlemlenen kıskançlık izleğinin temel nedenini özetlerken Türk romanındaki kıskançlığın psikoloji temelli olduğunu ifade etmeyi de ihmal etmez:

Kıskançlık duygusunun Türk romanında ele alınma biçimine bakıldığında ilk akla gelen bu duygunun geleneksel dinamiklerle çatışma yaratması bağlamında işlendiğidir. Ancak kıskançlık duygusunun ortaya çıkışı ile bireylerin içinde bulundukları toplum, yetişme şartları arasındaki ilişkinin içkin boyutu düşünüldüğünde 
kıskançlık duygusunun her kültürde psikolojik etkenlerle ortaya çıktığı gerçeği de göz ardı edilmemelidir. Bu nedenle Türk romanında -kadının tarihsel süreç içerisinde toplumdaki konumuna da bağlı olarak- ele alınan kıskançlık duygusunun ilk örneklerden itibaren psikolojik nedenselliklerle de kurgulandığı söylenebilir (s. 238).

Çalışma boyunca görülüyor ki kıskançlığın meydana çıkışı her ne sebeple olursa olsun gerek romandaki başkarakterin gerekse çevresindekilerin mahvına neden olan kötücül bir his olarak izlenir. Dr. Öğr. Üyesi Selda Uygur Gürbüz'ün psikanalitik yönden son derece titizlikle çalışılmış eseri yüzyıllarca paralellik arz etmiş psikoloji ve edebiyat biliminin yakınlıklarını bir kez daha gözler önüne sermeyi de ihmal etmez. Gürbüz'ün insanın en sahih hislerinden biri olan kıskançlığı metinlerdeki karakterler üzerinden irdeleyen çalışması okuyucuyu geniş çaplı bir düşünme sürecine davet etmesi bakımdan mühim bir örnek teşkil eder. Kıskançlığ çağdaş edebiyat metinleri üzerinden psikanalitik yöntemler ile değerlendiren bu eser, ilgili alanda çalışma yapacakların yolunu aydınlatacak ve büyük bir boşluğu dolduracak niteliktedir.

\section{KAYNAKÇA / REFERENCE}

Uygur Gürbüz, Selda (2021). Türk Romanından Örneklerle Edebiyat ve Klskançlık, İstanbul: Çizgi Kitabevi. 
